\title{
Erratum to: Effect of Aroma and Magnum Hops Extracts and Paracetamol on Antioxidant Liver Parameters in Mice
}

\author{
Vida Jakovljevic $^{1} \cdot$ Mira Popovic $^{2} \cdot$ Aleksandar Raskovic $^{1} \cdot$ Ana Sabo $^{1} \cdot$

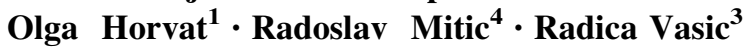

Published online: 24 August 2016

(c) Springer International Publishing Switzerland 2016

\section{Erratum to: Eur J Drug Metabol \\ Pharmacokinet (2009) 34:37-41 \\ DOI 10.1007/BF03191382}

This article was unintentionally published twice in this journal, by the same group of authors. Following should be considered the version of record and used for citation purposes: “\{Vida Jakovljevic, Mira Popovic, Aleksandar Raskovic, Ana Sabo, Olga Horvat, Radoslav Mitic and Radica Vasic\}, \{Effect of aroma and magnum hops extracts and paracetamol on antioxidant liver parameters in mice\}, \{European Journal of Drug Metabolism and
Pharmacokinetics\}, \{Volume 34, Issue 1, pages 37-41, 10. 1007/BF03191382\}".

The duplicate " $\{$ Vida Jakovljevic, Mira Popovic, Aleksandar Raskovic, Ana Sabo and Radica Vasic\}, \{Effect of aroma and magnum hops extracts and paracetamol on antioxidant liver parameters in mice\}, \{European Journal of Drug Metabolism and Pharmacokinetics\}, \{Volume 33, Issue 4, pages 205-209, 10.1007/ BF03190874\}" is to be ignored.

Springer apologizes to the readers of the journal for not detecting the duplication during the publication process.

The online version of the original article can be found under doi:10.1007/BF03191382.

Mira Popovic

popovic@ih.ns.ac.vu

1 Department of Pharmacology, Toxicology and Clinical Pharmacology, School of Medicine, University Novi Sad, Novi Sad, Serbia

2 Department of Chemistry, Faculty of Sciences, University of Novi Sad, Novi Sad, Serbia

3 Scientific Institute of Field Crops and Vegetables, Backi Petrovac, Republic of Serbia

4 Institute of Pharmacology, Faculty of Medicine, Pristina (Kosovska Mitrovica), Serbia 